\title{
Bauxite Deposits of the
}

Tippah-Benton District

Mississippi

GEOLOGICAL SURVEY BULLETIN 1199-C 


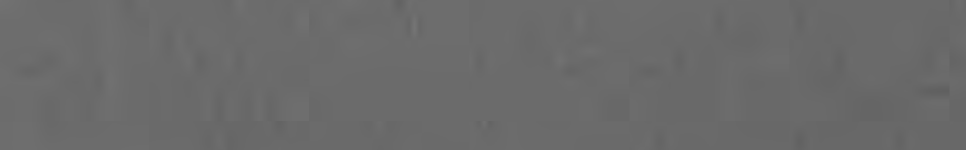

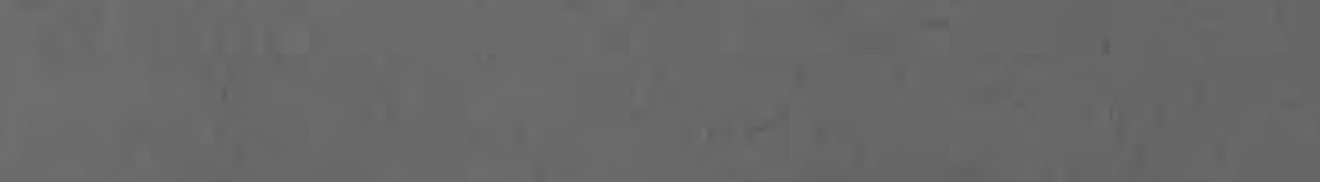
10

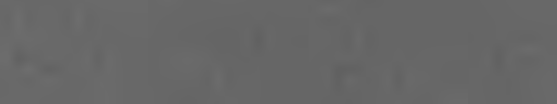

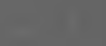

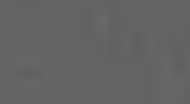

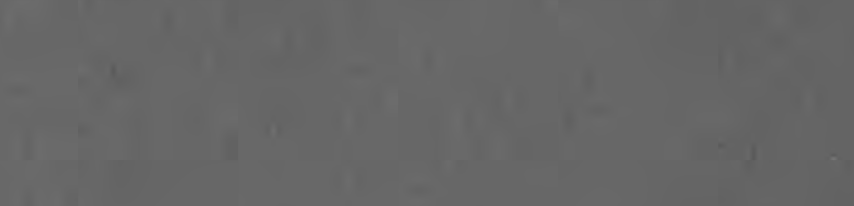

$$
\begin{aligned}
& \text { (1) }
\end{aligned}
$$

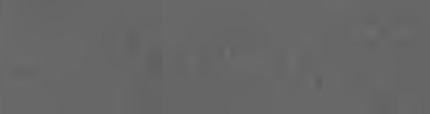

$$
\begin{aligned}
& -2
\end{aligned}
$$

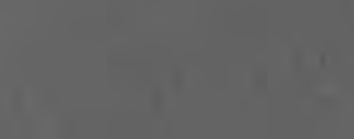

$$
13-1
$$




\section{Bauxite Deposits of the}

\section{Tippah-Benton District}

Mississippi

By HARRY A. TOURTELOT

BAUXITE DEPOSITS OF THE SOUTHEASTERN UNITED STATES

G E O L O G I C A L S U R V E Y B U L L E T I N 1199-C

Distribution and occurrence

of extensive low-grade

bauxite deposits

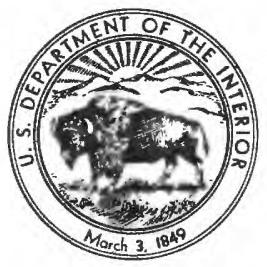




\section{UNITED STATES DEPARTMENT OF THE INTERIOR STEWART L. UDALL, Secretary}

\section{GEOLOGICAL SURVEY}

Thomas B. Nolan, Director

The U.S. Geological Survey Library has cataloged this publication as follows:

\section{Tourtelot, Harry Allison, 1918-}

Bauxite deposits of the Tippah-Benton district, Mississippi. Washington, U.S. Govt. Print. Off., 1964.

iv, 31 p. maps ( 2 fold., 1 col., both in pocket) diagr., tables. $24 \mathrm{~cm}$. (U.S. Geological Survey. Bulletin 1199-C)

Bauxite deposits of the southeastern United States Bibliography: p. $\mathbf{3 1 .}$

1. Bauxite-Mississippi. I. Title. II. Title: Tippah-Benton district, Mississippi. (Series) 


\section{CONTENTS}

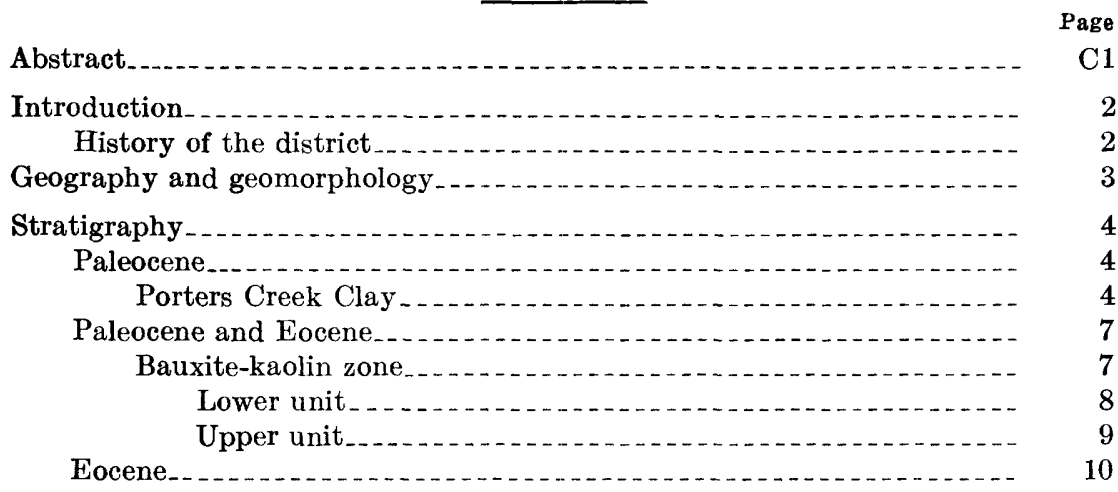

Wilcox Formation . 10

Bauxite and kaolin deposits...

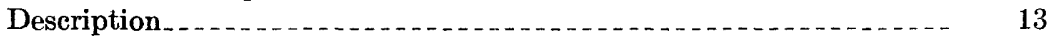

Classification of bauxite . .

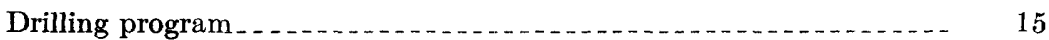

Finger area, Tippah and Benton Counties. 16

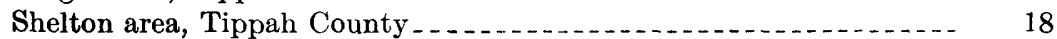

Shady Grove area, Tippah County ....................... 22

Blue Mountain area, Tippah County .....

Flat Rock Church area, Benton County ........... 25

Minor occurrences of bauxite and kaolin..................... 26

Tippah County

Hopper-Martindale-Holly Springs National Forest........ 26

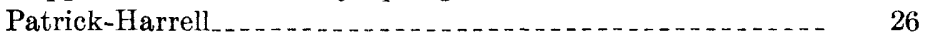

J. C. MeElwain ..................... 26

L. S. Pearce

I. V. James (Mississippi Bauxite Co.)

J. C. James (Mississippi Bauxite Co.) $\ldots \ldots \ldots$

Green Wattes (Mississippi Bauxite Co.) $\ldots \ldots \ldots \ldots$

W. M. Dodson _... 27

P. W. Caviness (Thad Hill)

J. P. Clemmer .

J. W. Jones. ...

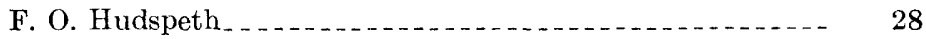

E. M. Hardin

C. F. Godwin

Benton County

J. R. Hunter

Reserves . . . .

Literature cited 31 


\section{ILLUSTRATIONS}

\section{[Plates are in pocket]}

Plate 1. Geologic map of the Tippah-Benton bauxite district, Tippah and Benton Counties, Miss., showing areas prospected by drilling.

2. Geologic maps of parts of Tippah and Benton Counties, showing location of drill holes in the Finger, Shady Grove, Flat Rock Church, and Shelton areas.

Figure 1. Generalized stratigraphic section for the Tippah-Benton bauxite district, Tippah and Benton Counties

2. Isopach maps of the bauxite and clay deposit found by drilling, Shelton area, Tippah County

\section{TABLES}

TABLE 1. Bauxite and kaolin deposits discovered by drilling in the

Tippah-Benton district, Mississippi.......................

2. Estimated reserves of bauxite and kaolin discovered by drilling in the Tippah-Benton district, Mississippi....... 


\title{
BAUXITE DEPOSITS OF THE SOUTHEASTERN UNITED STATES
}

\section{BAUXITE DEPOSITS OF THE TIPPAH-BENTON DISTRIGT, MISSISSIPPI}

\author{
By Harry A. Tourtelot
}

\begin{abstract}
The bauxite in Tippah and Benton Counties, Miss., is associated with kaolin in a zone of sediments that are transitional between the marine Porters Creek Clay of Paleocene age and the fresh-water sands and clays of the main part of the Wilcox Formation of late Eocene age.

The Porters Creek Clay, about 250 feet thick in Tippah and Benton Counties, consists primarily of dark-gray and black clay which, in the upper part, is laminated with streaks of fine-grained micaceous sand and grades upward into a white clay of the bauxite-kaolin zone. That zone is divided into two lithologic units. The lower unit, about 30 feet thick, consists of sand, sandy kaolin, silty kaolinitic clays, kaolin, kaolin conglomerate, and bauxite, all commonly containing pellets of siderite and concretions of granular siderite. This lower unit is considered to be the uppermosit part of the Porters Creek Clay. The upper unit, also about 30 feet thick, consists chiefly of dark carbonaceous and lignitic shales and clays, but a clay-ball conglomerate, locally containing many pisolites with a matrix of clayey siderite, is present at the base of the unit. This upper unit corresponds to the Fearn Springs Sand Member at the base of the Wilcox Formation. Most of the outeropping bauxite is part of the conglomerate at the base of the upper unit of the bauxite-kaolin zone, but most of the material of possible economic interest as a source of alumina is in the lower unit of the zone.

The main part of the overlying Wilcox Formation is as much as 200 feet thick. The lower part consists of coarse to fine sands and laminated silt interbedded with fine clayey sands in a jumble of beds of extremely local distribution. The upper part consists of sandy clay beds, thin lignitic streaks and, in most places, a hard siltstone containing vertical grass and reed prints.

Surface evidence suggests that the high iron content of the bauxite that crops out results from a concentration of the iron by ground water near the present land surface. The drilling program was designed to test bauxite under cover and to determine whether the iron content would be low and the alumina content correspondingly high. Five areas in the two counties were thus tested.
\end{abstract}

A total of 3,637,000 long tons of low-grade bauxite and kaolinitic clay was estimated from the drilling. The bauxite and clay occur as thin beds over 
large areas but beneath thick overburden. Most of the bauxite was low in grade. Additional material of similar quality might be found by further drilling, but the material would occur under the same conditions that are unfavorable for commercial development. Usable bauxite is unlikely to be found by drilling in areas where it does not crop out.

\section{INTRODUCTION}

Tippah and Benton Counties are in northeastern Mississippi adjacent to the Tennessee State line, about midway between the east and west boundaries of the State. Prospecting indicated the presence of a considerable quantity of low-grade bauxitic material. Study of the district was undertaken as a part of a cooperative program of the U.S. Geological Survey and the U.S. Bureau of Mines, in the hope that detailed studies would lead to discovery of usable material. The present report is based on field studies by the Geological Survey and information obtained from the drilling program of the Bureau of Mines. The first part of the investigation of the deposits by the Geological Survey was a reconnaissance survey made in the spring of 1942 by L. C. Conant, who submitted preliminary recommendations for drilling to the Bureau of Mines in June of that year. The author worked in the district from June 1942 to January 1943 and May to September 1943 and submitted supplemental drilling recommendations in October 1942.

The bauxite was found to be restricted to a narrow zone in the upper part of the Paleocene and in the lower part of the Eocene. This zone was mapped and prospected over an area of several townships in Tippah and Benton Counties. The base map (pl. 1) was prepared from aerial photographs with the assistance of E. B. Parmalee and W. R. Griffitts. A Bureau of Mines hand-auger crew operated in the area during August 1942; the Works Progress Administration of Mississippi furnished the Geological Survey with a four-man hand-auger crew from September 1942 to January 1943. These crews obtained samples and information regarding the extent of many of the bauxite deposits.

From May 25 to July 10, 1943, the Bureau of Mines conducted a drilling project with D. F. Reed in charge. The drill cores were logged by W. B. Baldwin, Hanford Drummond, and James Morris of the Geological Survey. The results of the drilling have been published by the Bureau of Mines (Reed, 1948).

\section{HISTORY OF THE DISTRICT}

The first mention of bauxite in Mississippi was by E. W. Hilgard $(1860$, p. 14), who described a "singular rock *** much resembling a true puddingstone" near Blue Mountain, Tippah County. In 
1921, J. W. Adams of Sheffield, Ala., who was interested in bauxite and bauxitic clay in northwestern Alabama, studied Hilgard's report in hope of finding mention of bauxite in Mississippi. Suspecting that Hilgard's "puddingstone" was bauxite, Adams visited the Blue Mountain locality and collected samples which, upon examination and analysis, were found to be bauxite. During the next few months, he prospected northeastern Mississippi and found nearly all the major occurrences of bauxite and bauxitic material known in the State.

On the basis of the prospecting done by Adams, the Mississippi Bauxite Co. was formed at Sheffield, Ala., and W. C. and P. F. Morse, then consulting geologists, Starkville, Miss., were engaged to determine the quality and quantity of ore present on the various properties under lease to the company. The results of the Morses' work (1923) were published by the Mississippi Geological Survey. The Mississippi Bauxite Co. later bought several of the more promising deposits prospected, including the I. V. James and Green Wattes properties in Tippah County. At about the same time, the Ashland Exploration and Development Co., Ashland, Miss., under the direction of George L. Stevenson, became active in the district and obtained leases on several properties. In $1925, \mathrm{Mr}$. W. D. Shelton discovered the Meadows bauxite deposite north of Shady Grove (pl. 1). This deposit was the last large deposit found in the district. In 1942, the Mississippi Ore Co. was organized at Ripley, Miss., and obtained leases on several properties.

A report of the U.S. Geological Survey by E. F. Burchard (1925), who visited the district in 1923, summarized the prospecting done by the Morses, described several deposits in Tippah and Benton Counties which had not been prospected by the Morses, and offered suggestions as to the genesis of the bauxite. In 1938, the Mississippi Geological Survey with the cooperation of the Work Projects Administration made a mineral survey of Tippah County. L. C. Conant, the geologist in charge, prepared a geologic map of the county and prospected several kaolin bodies and the Meadows bauxite deposit (Conant, 1941).

Although most of the bauxite properties have been under lease many times to various interests and several are owned by the Mississippi Bauxite Co., there has never been any commercial mining in the district. In September 1942, the Bureau of Mines removed 50 tons of high-iron bauxite from the Meadows property for experiments with the Pederson electric furnace process and another 50 tons in September and October 1943 for the same purpose.

\section{GEOGRAPHY AND GEOMORPHOLOGY}

The outcrops of bauxite and bauxitic material described herein are mainly in five areas: three in Tippah County, one in Benton County, 
and one straddling the county line (see pl. 1). Areas in Tippah County are (1) the Shelton area, 10 miles northwest of Ripley, (2) the Shady Grove area at, and north of, Shady Grove, and (3) the Blue Mountain area, half a mile north of Blue Mountain. The Benton County area is at Flat Rock Church 4 miles west of Blue Mountain; and the area partly in both counties, the Finger area, is 5 miles west of Falkner. Small isolated outcrops lie near and between these major occurrences but chiefly in Tippah County.

The bauxite deposits lie along the west border of the East Gulf Coastal Plain. The major bauxite occurrences are in the North Central Hills belt near their boundary with the Flatwoods belt (Fenneman, 1938, p. 73-74; Conant, 1941, p. 14-15). The Flatwoods is a low-lying featureless belt 2 to 6 miles wide that is underlain by the Porters Creek Clay of Paleocene age. The North Central Hills are underlain chiefly by Wilcox sediments of Eocene age and have a maximum relief of about 200 feet. Between the Flatwoods and the North Central Hills is an area of moderate relief corresponding somewhat to the transitional beds between the Wilcox Formation and the Porters Creek Clay.

The irregularly shaped masses of hard bauxite have resisted erosion and are now found capping small isolated hills or forming prominent terraces on the edges of the larger hills.

\section{STRATIGRAPHY}

The Porters Creek Clay of Paleocene age and the Wilcox Formation of early Eocene age crop out in the Tippah-Benton district. The bauxite and kaolin are in the uppermost part of the Porters Creek Clay and in the Fearn Springs Sand Member at the base of the Wilcox Formation. These parts of the Porters Creek and Wilcox Formations are described together as the bauxite-kaolin zone. The stratigraphic units in the Tippah-Benton district are shown in a generalized stratigraphic column in figure 1.

\section{PALEOCENE}

\section{PORTERS CREEK CLAY}

The oldest formation cropping out in the district (pl. 1 and fig. 1 ), is the Porters Creek Clay. It consists of the Chalybeate Limestone Member at the base and the overlying dark-gray clay of the main part of the formation.

The Chalybeate Limestone Member is about 80 feet thick at the type locality in the town of Chalybeate, sec. 3, T. 2 S., R. 4 E., Tippah County, but it thins southward. In the vicinity of Ripley, it consists of fossiliferous limestone, marl, leaf-bearing shales, glauconitic sand, and fossiliferous siltstone. 


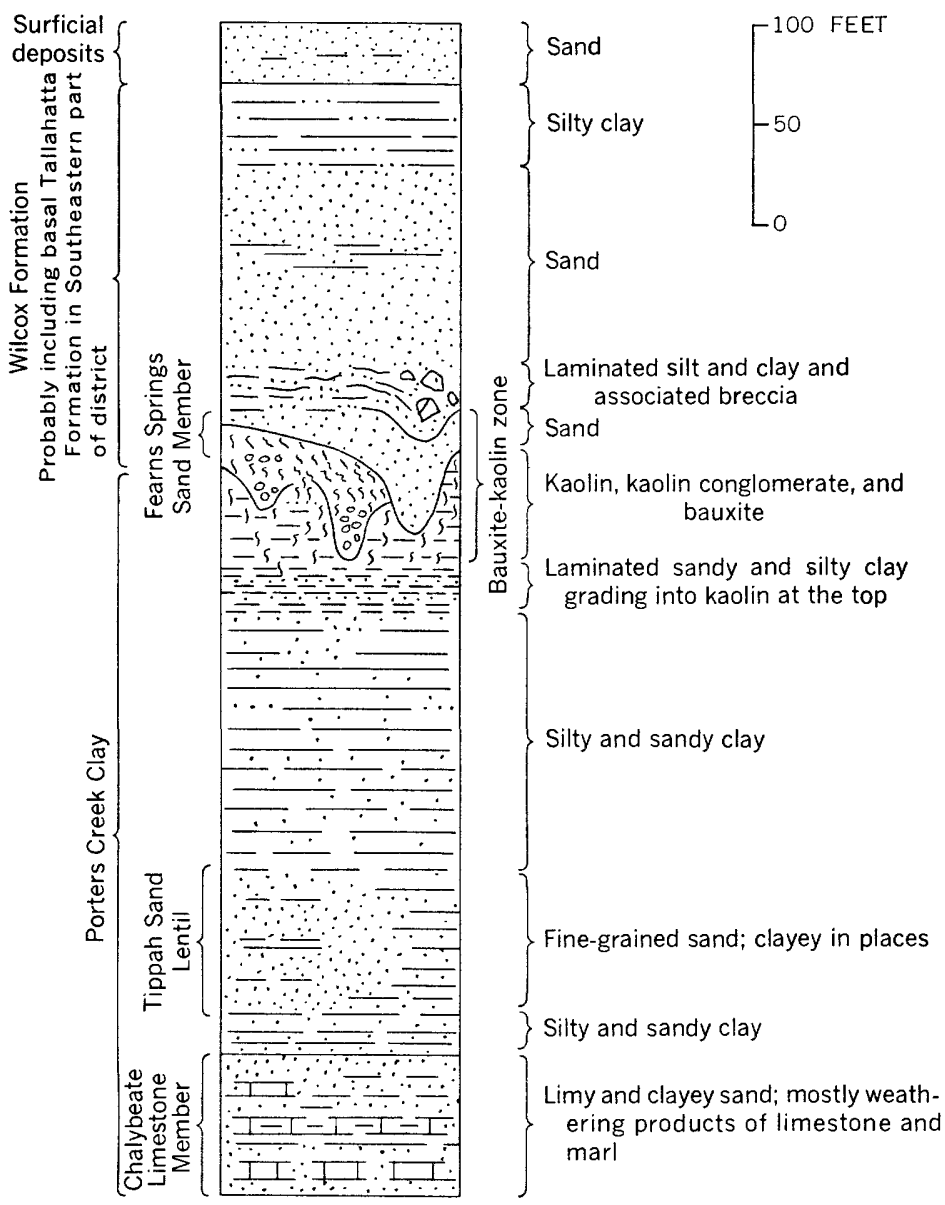

Figure 1.-Tippah-Benton bauxite district, Tippah and Benton Counties, Miss. Modified from Conant (1941) and MacNeil (1946).

The main part of the Porters Creek Clay consists primarily of darkgray clay that is extremely plastic when wet and has a marked conchoidal fracture. Although the Porters Creek Clay weathers into the featureless low-lying Flatwoods belt over most of its outcrop area, along the contact with the overlying sediments considerable relief is evident. Conant (1941, p. 33) estimated that the Porters Creek Clay was 200 to 250 feet thick in Tippah County and that the contact between this formation and the overlying Wilcox Formation dipped westward about 15 feet to the mile.

The Porters Creek above the Chalybeate Limestone Member is typically a dark-colored silty and micaceous marine clay that includes scattered zones of glauconitic clay and rare limestone nodules. At the 
top of the formation the clay beds are laminated, and in places the uppermost several feet is white clay. In Tippah County, unconsolidated white to yellow glauconitic sand beds aggregating about 80 feet in thickness in the lower part of the formation have been designated by MacNeil (1946, p. 10-11) as the Tippah sand lentil.

Glauconite is fairly common locally in both the clay and sand seams, and it is usually accompanied by obscure casts and molds of marine animals. These fossiliferous glauconitic zones may be seen at the following localities: on the Antioch road, 3 miles northwest of Ripley, where 85 feet of Porters Creek Clay is exposed in the road ditches and banks (near the center of sec. 9, T. 4 S., R. 3 E.) ; $4 \frac{1}{2}$ miles northwest of Ripley in a small wash a few yards east of the road near the top of the hill on the south side of a branch (SE1/4NW1/4 sec. $4, \mathrm{~T} .4 \mathrm{~S}$., R. 3 E.) ; and on the Saulsbury road, $4 \frac{1}{2}$ miles north of Ripley (near the center of the south line of sec. 26 , T. 3 S., R. 3 E.) in the roadcuts on both sides of the stream. Conant (1941, p. 33-34) reported glauconitic beds at several horizons in the lower part of the Porters Creek Clay above the Chalybeate Limestone Member.

A soft black massive clay, as much as 5 feet thick, containing small iron sulfide concretions, is found locally at the top of the Porters Creek Clay. It is well exposed in the roadcut at the glauconite locality $4 \frac{1}{2}$ miles north of Ripley on the Saulsbury road and in a gully on the J. D. Ketcham property (SE1/4SE1/4 sec. 14, T. 3 S., R. 3 E.). The soft clay is overlain by a thick section of sand at all outcrops. It is possibly a decomposition product of the Porters Creek Clay. Such clay seems to be present wherever Porters Creek Clay containing iron sulfide is overlain by sand.

The laminated clay at the top of the formation is the only unit described in detail in this study, and the dark-colored part of it is referred to informally as the black laminated Porters Creek Clay. The clay is present as lenses, grading laterally and downward into the typical massive clay of the Porters Creek which breaks with a conchoidal fracture. The laminated clays are dark gray to black and have very thin seams of fine micaceous sand between the clay laminae. Mica is present in minor amounts within the clay laminae and is parallel to the bedding planes. Concretions of granular siderite occur along the bedding planes at many places, and small concretions of iron sulfide have been found at a fow localities. Carbonaceous material and fragmentary plant remains were found in the black laminated Porters Creek Clay penetrated in some drill holes. Where the top several feet of the laminated Porters Creek is light gray or white in color, rather than dark gray or black, the clay is informally referred to as the white Porters Creek Clay. The lam- 
inated Porters Creek is well exposed for about three-quarters of a mile along the road running west from Blue Mountain, and it is widely exposed in southeastern Benton County. Everywhere in the district, drill holes penetrated laminated clays beneath the lower unit of the bauxite-kaolin zone.

In the Tippah-Benton district, the author has mapped the top of the black laminated Porters Creek Clay instead of the top of the formation. The overlying several feet of white Porters Creek Clay, therefore, where present, has been mapped with the Wilcox Formation because lack of outcrops, heavy colluvium from the overlying Wilcox Formation, and similarities between clay of the Wilcox and at the top of the Porters Creek made tracing the true contact between the formations impractical in the available time. Inasmuch as bauxite was known to be restricted to an interval 10 to 40 feet above the black laminated Porters Creek Clay, the chosen contact was no hindrance in exploration.

\section{PALEOCENE AND EOCENE}

\section{BAUXITE-KAOLIN ZONE}

The bauxite-kaolin zone consists of nonmarine sediments of the uppermost kaolinitic part of the Porters Creek Clay (the white Porters Creek Clay), where present, and of the lower bauxitic and kaolinitic part of the Wilcox Formation, identified as the Fearn Springs Sand Member by MacNeil (1946, p. 18-19). Most of what is known about the bauxite-kaolin zone in Tippah and Benton Counties has been learned from the cores and samples obtained during the U.S. Bureau of Mines drilling for bauxite. Outcrops are few and generally do not show more than one or two of the several kinds of sediments in the zone.

The sediments of the bauxite-kaolin zone have been mapped with the Wilcox Formation. They may be grouped into two lithologic sequences which will be called the lower and upper units of the bauxite-kaolin zone. The lower unit corresponds approximately to the white Porters Creek Clay and the upper unit to the Fearn Springs Sand Member of the Wilcox Formation. The contact between the units may be gradational or erosional, and each unit contains within itself intraformational channels. The uncertainties of interpreting complex sedimentational and stratigraphic relationships from scattered drill cores makes the informal subdivision of the zone into units preferable to assigning parts of the zone to formal stratigraphic units.

The bauxite-kaolin zone is commonly 50 to 60 feet thick but reaches a maximum thickness of 88 feet. The total of the maximum thicknesses of the various beds in the zone would be more than 100 feet.

The zone has been preserved in a long narrow area close to the 
present Paleocene-Eocene contact. Several miles east of the exposed contact, the zone, if ever present, has been removed by subsequent erosion. There is little evidence that the zone ever extended very much farther to the west, that is downdip, than found at present, although some clay was undoubtedly removed prior to deposition of the upper sands of the Wilcox.

Rounded and angular fragments of kaolin and kaolinitic clay are scattered throughout the bauxite-kaolin zone and are concentrated at several levels as beds of kaolin conglomerate. Many of the fragments are bleached around their borders, and the periphery of the fragments commonly is marked by a thin dark band. These beds of kaolin conglomerate, as much as 5 feet thick, have sharp lower contacts in some places and locally contain fine sand. Such conglomerates are probably most common at the base of intraformational channels within the lower unit of the bauxite-kaolin zone. In some places material filling channels rests on the lower sediments of the zone and in others on the black Porters Creek Clay, a fact which reflects channels of different sizes and depths to which they were eroded. The kaolin above the conglomerate is identical in appearance with the kaolin of nonchannel sections.

Vertical streaks of a breccia consisting of kaolin and lignite fragments in a matrix of dark-gray clay are present in many cores throughout the bauxite-kaolin zone. Some of the streaks are as much as 2 feet long, but they are seldom more than 1 inch wide. These streaks have definite and sharp boundaries. At the time of deposition the dark-colored clay matrix was soft and wet, as the kaolin fragments commonly are broken and the dark clay appears in the cracks. If these vertical streaks are filled desiccation cracks, they indicate that the kaolin was deposited in areas subject to flooding and drying.

\section{LOWER UNIT}

The lower unit of the zone is 12 to 38 feet thick at most places and averages about 30 feet. A few miles south and west of the TippahBenton district, the lower unit of the bauxite-kaolin zone is locally absent, and so the upper unit rests directly on the Porters Creek Clay.

The black laminated Porters Creek Clay grades upward into the lower unit of the bauxite-kaolin zone through laminated white Porters Creek Clay into a light bluish-gray or white massive kaolinitic clay. The gradation is in part due to a decrease in the amount of micaceous sand between the laminae, thus the uppermost part of the white clay is free from such sand. The thickness of the laminated white clay averages about 3 feet but ranges from 1 to 9 feet. In some places 
a few inches of coarse sand is found between the kaolinitic clay and the white laminated Porters Creek Clay.

When moist, the kaolinitic clays and kaolin of the lower unit are medium to light bluish gray, but when dry, they are a light bluish gray or white. The kaolin is commonly contaminated by silt, fine sand, and siderite, but beds of kaolin as much as 10 feet thick may be nearly or completely free of contamination. The clean kaolins range from plastic to slightly plastic and in most places are near the top of the lower unit of the bauxite-kaolin zone. Siderite occurs as hard granular concretions or as pellets as much as $1 \mathrm{~mm}$ in diameter scattered sparsely through the kaolin or concentrated into nearly solid masses. The concretions of hard granular siderite are most common in the upper part of the kaolin and may be as much as 2 feet thick. The pellets of siderite are most abundant in the lower part of the kaolin and the upper part of the white Porters Creek Clay. Silt and sand may contaminate the whole kaolin section but are most common near the top and bottom. Gypsum crystals have also been observed in these clays on the outcrops.

Kaolin and kaolin conglomerate in the lower unit may have silicaalumina ratios of 1 or less and contain gibbsite or some other hydrous aluminum oxide. Such bauxitic clay in the lower unit of the zone forms most of the material found by drilling to be of possible commercial value as a source of alumina.

\section{UPPER UNIT}

The upper unit of the bauxite-kaolin zone rests on the lower unit only in the narrow north-south belt in which the bauxite is found. The greatest thickness of the upper unit observed in drill holes was 61 feet, and the average thickness was about 30 feet. The thickness of the upper unit measured west of the bauxite belt is 70 feet, and it is probably even greater farther west. The upper unit is characterized by carbonaceous and lignitic material interspersed throughout, but particularly in the silty or sandy parts.

In some drill holes, the silty and sandy micaceous clay at the top of the lower unit grades upward into dark-colored clay, shale, and lignite of the upper unit. In other drill holes, a clay-ball conglomerate that is commonly sandy or a fine micaceous sand containing lignite fragments lies on the eroded surface of the lower unit and is overlain by similar dark-colored clay and shale beds. On the outcrop, these dark-colored clay and shale beds have weathered to light gray, white, or buff.

The clay-ball conglomerate has a maximum thickness of 40 feet at the Meadows bauxite deposit but elsewhere is only about 10 feet thick. The conglomerate consists of varicolored bauxitic pisolites 
and of more or less rounded silty micaceous clay balls, which are red, tan, and gray all in a matrix of sandy, sideritic clay. Crystalline as well as granular siderite is present in the conglomerate. The crystalline siderite lines cavities and cracks that cut across the pisolites, clay balls, and matrix. The clay balls were probably derived from the silty and sandy micaceous clay which is just above the kaolin of the lower unit of the bauxite-kaolin zone, and the pisolites may have been eroded from bauxitic material in the upper part of the lower unit and deposited with the clay balls. The pisolites vary in abundance both vertically and horizontally. In a few drill cores and outcrops, the pisolites are so numerous that the conglomerate contains considerable alumina. Exposure or suitable ground-water conditions have oxidized the siderite to limonite and hardened the conglomerate.

At the Little Hope Crossroads (NE1/4 SE1/4 sec. 5, T. 3 S., R. 3 E.), 4 miles west of Falkner, about 4 feet of basal sand of the upper unit of the bauxite-kaolin zone rests on a kaolin conglomerate within the lower unit of the zone. The sand grades upward into a partly indurated ledge of siltstone, 8 inches thjck, which contains very poorly preserved prints of roots or grass blades. About 1 foot of lignitic and carbonaceous sandy clay rests on the siltstone. Above the lignite, petrified wood occurs in the lower 3 or 4 feet of a 28-foot sequence of light-colored clayey silt. This exposure is the only one noted in Tippah and Benton Counties at which petrified wood may be seen in place. Crystalline gypsum occurs in the clay above a lignite bed just east of the crossroads.

In an abandoned road (NE $1 / 4$ NE $1 / 4$ sec. 24 , T. 3 S., R. 2 E., Tippah County), poorly preserved fresh-water mussels of the family Unionidae have been found as float downhill from an outcrop of gray shaly clay underlain by dark-colored clay containing carbonaceous seams. These clays are part of the upper unit of the bauxite-kaolin zone and rest on laminated and micaceous Porters Creek Clay. Mussels have also been found in the debris downhill from outcrops of similar clays half a mile to the north across the creek in Benton County. Similar mussels have been found in washes below outcrops of gray shaly clay half a mile south of the McGill-Tapp bauxite deposit (SE1/4 sec. 12, T. 3 S., R. 2 E., Benton County).

\section{FOCENE}

\section{WILCOX FORMATION}

The Wilcox Formation in Mississippi is equivalent to the Wilcox Group of Alabama and Georgia and represents all the lower Eocene. The Fearn Springs Sand Member is at the base of the formation and was described in the preceding section. 
The Fearn Springs Sand Member is the only part of the lower Eocene which could be mapped separately from the rest of the Wilcox Formation. The Fearm Springs is not everywhere present along the strike, in part owing to erosion prior to deposition of the overlying sands of the main part of the Wilcox Formation and probably in part owing to nondeposition and penecontemporaneous erosion in Fearn Springs time. The Fearn Springs is characterized by a wide variety of lithologic types. In most exposures it is a micaceous sand, but the lignitic sand and gray and white clay beds and bauxite of the upper unit of the bauxite-kaolin zone constitute the Fearn Springs in a narrow north-south belt through the central part of the district.

Fine-grained micaceous sand, characteristic of the Fearn Springs, is exposed in and near a cut on the Antioch road 6 miles northwest of Ripley (SE $1 / 4 \mathrm{SE} 1 / 4$ sec. 29 , T. 3 S., R. 3 E.), about $1 \frac{1}{2}$ miles south by southwest of the Shelton area. The sand is 55 feet thick and includes a lens of gray clay 10 feet thick near the top and another similar lens 6 feet thick near the middle. Each of the two clay lenses contains a bed of carbonaceous clay. Samples from auger holes showed the sand to be resting on the Porters Creek Clay. Laminated clayey silt and fine argillaceous sand of the overlying part of the Wilcox Formation are exposed above the micaceous sand, but a 5-foot covered interval conceals the contact. About 35 feet of similar micaceous sand containing lenses of light-brown clay, is exposed several miles to the northwest where the road crosses Caney Creek (NW1/1 sec. 25 , T. 3 S., R. 2 E.), just above the creek level on the east side of the creek. An auger hole in the road ditch showed this sand to extend at least 9 feet below the creek level. The hole was abandoned at that depth because of caving. Gray shaly clay above the sand on the west side of Caney Creek contains plant remains.

The predominant materials of the Wilcox Formation above the Fearn Springs Sand Member, from bottom to top, are (1) nonmarine moderately coarse to fine sand, (2) interbedded horizontal and crossbedded laminated clayey silt and fine clayey sand, and (3) light-colored silty clay and lignite beds. A coarse sand that in places overlies the uppermost clays is probably the basal part of the Tallahatta Formation of middle Eocene age but was not mapped separately. The light-colored silty clays at the top of the Wilcox Formation are the only material found consistently at the same stratigraphic position. The underlying sands and silts have only local distribution. Local environment seems to have controlled the deposition of these sediments. Where the volume of water was greatest and the currents most active, the , coarse sand was deposited, whereas in areas of relatively quiet water, the laminated clayey silt and fine clayey sand were deposited. 
Erosion penecontemporaneous with deposition produced striking brecciation.

The main body of Wilcox sediments above the Fearn Springs was deposited on a very uneven surface and lies on either the black laminated Porters Creek Clay, sands of the Fearn Springs, or some part of the bauxite-kaolin zone. The total thickness is as much as 200 feet. Channeling partly or wholly removed the bauxite-kaolin zone. Where the Wilcox sands or laminated silts lie on the black Porters Creek Clay, such places are topographic lows on the early Wilcox surface. Where fine sands or clays of the upper part of the Wilcox rest on the bauxite-kaolin zone, these places were hills on the early Wilcox surface.

At most places where the Porters Creek Clay is directly overlain by the main body of the Wilcox, the Porters Creek consists of moderately coarse sand free from clay and locally bearing some fine gravel or thin streaks of clay balls at the base. The sand is commonly red owing to iron oxide, but in some places it is white or tan. Mast of the coarse sand is found in the eastern part of the area of Wilcox outcrop, near the base of the formation. The sand pits north of Ripley and east of Blue Mountain are in the coarse sands of the formation. Limonite, deposited in the sand at many places, forms thin beds and irregularly fluted masses of ferruginous sandstone. Wicker Mountain, a prominent hill about 3 miles north of Ripley (SW1/4 SW1/4 sec. 25 , T. 3 S., R. 3 E., Tippah County), is capped by a 6 -foot bed of such ferruginous sandstone. In the sand at, and northwest of, Blue Mountain, the limonite has been deposited in the form of tubes and pipes about one-half inch in diameter and an inch or two long.

The sand is commonly about 30 feet thick but varies considerably in thickness; it is 100 feet thick at Blue Mountain and 55 feet thick in the sand pits north of Ripley.

In many places, interbedded clayey silts and fine-grained clayey sands, stratigraphically higher in the Wilcox, fill channels which have cut through the sand beds and rest on the bauxite-kaolin zone or on the Porters Creek Clay. Angular and rounded fragments of laminated clayey silt, ranging from 1 inch to 3 feet in diameter, are common near the base of such intraformational channels. Crossbedding of both the clayey sands and the laminated clayey silts is striking in some places, and the laminated clayey silts locally are greatly contorted and brecciated. The contortion and brecciation are probably due to slumping after the erosion of a nearby channel. In most exposures the clayey sand and laminated silt occur in alternate beds, but in some exposures only sand or only laminated silt is present. In the vicinity of the Meadows bauxite deposit, some of the conglomerate at the base of the upper unit of the bauxite-kaolin zone has been reworked into this clayey sand which rests directly on the Porters Creek Clay. 
The sand is clayey, but the clay is present in small pellets, about twice as large as the average grain size of the sand. When dry, the light-colored pellets of clay give the sand a characteristic "milky" appearance. A fow dark-colored shale pellets are scattered through the sand in some places.

The laminae of the clayey silts generally range from $1 / 16$ to $1 / 2$ inch in thickness; they are commonly about a quarter of an inch thick. Mica is locally present, and some of the silt beds are sandy. In most outcrops, the sand and laminated clayey silt beds are orange brown, grayish orange, or red, but where protected from weathering by deep cover, they are olive drab.

Two sections of laminated silt and sand, measuring 70 feet (northsouth road in the NE1/4 sec. 21 , T. 3 S., R. 3 E.) and 85 feet (along the road in the $\mathrm{E} 1 / 2$ sec. $20, T$. $3 \mathrm{~S}$., R. $3 \mathrm{E}$.), probably represent the average thickness of such material in the district.

The silty clay beds at the top of the Wilcox Formation are present in only a few localities within the area studied. In Benton County, they are best exposed just below coarse sands at Flat Rock Church. The best exposures in Tippah County are at the following localities: the NE1/4 sec. $20, \mathrm{E}_{1} 1 / 2$ sec. $30, \mathrm{NW}^{1 / 4}$ sec. 25 , and $\mathrm{W}^{1 / 4}$ sec. 18 , all in $\mathrm{T}$. $3 \mathrm{~S}$., R. $3 \mathrm{E}$. The clay beds are very silty and in places include much fine sand. In some places one or more beds of black or dark-gray carbonaceous clay contrast sharply with the white or light-gray clays. A bed of hard, clayey silt, 1 to 2 feet thick, bearing prints of reeds and grasses, crops out near Flat Rock Church, Benton County, and 10 miles northwest of Ripley on the Saulsbury $\operatorname{road}(\mathrm{NE} 1 / 4 \mathrm{sec} .20$, T. $3 \mathrm{~S}$., R. 3 E.), Tippah County. The upper clay beds of the Wilcox Formation are rarely more than 30 feet thick.

\section{BAUXITE AND KAOLIN DEPOSITS}

\section{DESCRIPTION}

In the Tippah-Benton district the bauxitic materials range in appearance from typical pisolitic bauxite through clay-ball conglomerate to material having the earthy appearance of kaolinitic clay. The correlation between physical characteristics and the alumina content of these materials is poor. The minerals gibbsite $\left(\mathrm{Al}_{2} \mathrm{O}_{3} \cdot 3 \mathrm{H}_{2} \mathrm{O}\right)$ and kaolinite $\left(\mathrm{Al}_{2} \mathrm{O}_{3} \cdot \mathrm{SiO}_{2} \cdot 2 \mathrm{H}_{2} \mathrm{O}\right)$ are the chief constituents, but theoretically the proportions of these minerals may range from almost pure gibbsite to pure kaolinite. The highest grade of pisolitic bauxite discovered in drilling contained 49.0 percent alumina and 14.0 percent silica, but most pisolitic bauxite found in the district contains much less alumina. Earthy bauxite in general contains less alumina than 
pisolitic bauxite, and the highest grade of this type discovered in drilling averaged 43.2 percent alumina for a 4 -foot interval.

Bauxitic materials are somewhat different in the upper unit than in the lower unit of the bauxite-kaolin zone. Most of the material of possible commercial interest is in the lower unit which has deposits of greater size and somewhat higher alumina content. However, most of the material known from outcrops is a part of the upper unit.

Most of the bauxite of the earlier investigators was the conglomerate at the base of the upper unit of the bauxite-kaolin zone. The outcrops on the McGill-Tapp, Shelton-National Forest, Thompson EstateNational Forest, and the Meadows properties are of this conglomerate. Bauxite at the base of the upper unit of the zone is very ferruginous. On outcrop, the bauxite is hard, but in test pits and drill holes it is fairly soft unless granular siderite fills the interstices. On casual inspection the bauxite seems to consist of abundant pisolites in a ferruginous clay matrix, but on closer examination irregular but rounded clay balls also are seen to be present among the pisolites. In some places clay balls are more abundant than pisolites, and in others the pisolites are more prevalent. A few pisolites are commonly present even if clay balls predominate in the rock, and a few clay balls can be found in the most pisolitic bauxite of this type. Pisolites are more prominent in the outerops than in test-pit and drill-hole samples. Few of the pisolites are more than a quarter of an inch in diameter, but some of the clay balls are as much as 1 inch in diameter. Color of pisolites ranges from dark reddish brown in hard ferruginous bauxite to red or light brown and gray in soft or hard sideritic bauxite.

Bauxite in the lower unit of the bauxite-kaolin zone may be either nonpisolitic or pisolitic. The nonpisolitic bauxite is soft and clayey and is difficult to distinguish in appearance from kaolin. It is perhaps less plastic than the kaolin, but plasticity was not found to be a dependable criterion for the recognition of either. Most of the pisolitic bauxite is fairly hard. Pisolites range from about $1 / 10$ to 1 inch in diameter. Oolites are less than about a tenth of an inch in diameter. Compound pisolites consist of several small pisolites or oolites enclosed together in a shell. The largest pisolites are the compound ones found at the I. V. James and Guyton bauxite deposits. Both the nonpisolitic and the pisolitic bauxites are white or light gray, except where they are stained red or light brown by iron oxide.

The principal differences between pisolitic bauxite and kaolin conglomerate, which resembles the bauxite, are the presence in the bauxite of kaolin fragments surrounded by a shell, in which most of the gibbsite probably occurs, the presence of pisolites consisting largely of 
gibbsite, and an increase in hardness of the conglomerate. 'The matrix of both the kaolin conglomerate and the bauxite is largely kaolinite. Kaolin and kaolinitic clays are closely associated with the bauxite and occur above, beneath, or within the bauxite in no consistent order.

\section{CLASSIFICATION OF BAUXITE}

A modification of the Thoenen-Burchard bauxite classification (Thoenen and Burchard, 1941, p. 38) was used in grading the material found in Tippah and Benton Counties. In the unmodified classification, grade $\mathrm{D}$ is material containing 30 to 45 percent alumina regardless of the iron and silica content. In this report grade $\mathrm{D}$ is restricted to material which contains more alumina than silica, regardless of the iron content. Only material falling in this or higher grades is called bauxite. That material which contains more silica than alumina is called kaolinitic clay or clay and may contain some gibbsite or sand as well as siderite and limonite, in addition to kaolinite. The restriction of grade $\mathrm{D}$ is desirable because it segregates material generally referred to as bauxitic clay, containing some gibbsite, from that which is primarily kaolin. The modified classification used for the TippahBenton County district is as follows:

\begin{tabular}{c|r|l}
\hline \multicolumn{1}{c|}{ Grade } & Alumina (percent) & \multicolumn{1}{|c}{ Silica (percent) } \\
\hline A & +55 & Less than 7. \\
\hline B & $50-55$ & Less than 15. \\
Kaolinitic clay & $45-50$ & Less than 30. \\
& $30-45$ & Less than alumina. \\
\hline
\end{tabular}

\section{DRILLING PROGRAM}

The purpose of the U.S. Geological Survey-Bureau of Mines joint drilling program was to find usable bauxite in Tippah and Benton Counties. Most bauxite found on outcrop is so high in iron oxide that the alumina content is necessarily low, but analyses (Morse, 1923) and logs of deep test pits near the outcrops showed that the bauxite on the surface contains more iron oxide than that below the surface. The iron oxide is probably due largely to a secondary concentration related to the present ground surface, and the bauxite penetrated under cover may be free of iron oxide. Therefore, one of the aims of the drilling program was to test bauxite under cover in favorable areas.

Five areas, some adjacent to major bauxite outcrops, were favorable for testirg. These were the Finger, Shelton, Shady Grove, Blue Mountain, and the Flat Rock Church areas. The locations of the 
52 holes drilled were selected by the Bureau of Mines project engineer on the basis of recommendations made by the Geological Survey. The drilling program was flexible in operation, and proposed hole sites were relocated or eliminated as the drilling progressed. The Geological Survey staff described the cuttings and cores and selected core samples for analysis. Unless otherwise credited, all the analyses presented herein were made in the Bureau of Mines laboratory at Tuscaloosa, Ala. (Reed, 1948).

Tonnage estimates were made from isopach maps of the clay and bauxite deposits in the Shelton and Shady Grove areas. In the Shelton area, outcrops and topographic features partly defined the edges of the deposit. Where the material did not crop out, the clay and bauxite were assumed to thin to a feather edge halfway between the barren holes and holes showing clay and bauxite. In those parts of the body where no limiting outcrops or holes were present, the deposit was assumed to thin to a feather edge along a line that conformed to the general shape of the body as indicated by outcrops and the thickness of clay and bauxite in the drill holes.

In the Finger, Blue Mountain, and Flat Rock Church areas, few data are available, and tonnage estimates are based on the average thickness of bauxite and clay penetrated in a few scattered drill holes. In delimiting the area believed to be underlain by bauxite and clay, the bauxite and clay were assumed to be continuous between drill holes as much as half a mile apart. This assumption is decidedly untrustworthy in view of the lenticular nature of the bauxite and clay, the great variations in quality which may take place within short distances, and the possibility of pre-Wilcox erosion. The area indicated by the drilling to be underlain by clay and bauxite was modified to compensate for the variables described in the sections on these areas.

\section{FINGER AREA, TIPPAH AND BENTON COUNTIES}

The Finger area, named from the Finger School, lies along the west edge of Tippah County in secs. 6 and 7, T. 3 S., R. 3 E. and the east edge of Benton County in secs. 1 and 12, T. 3 S., R. 2 E., about 5 miles west of Falkner. The bauxite outcrops and the holes drilled by the U.S. Bureau of Mines are shown on plate2.

\section{OUTCROP}

Boulders of hard bauxite, clay-ball conglomerate, and silty clays of bauxite-kaolin zone crop out in several places along the small drainage line which heads south of Finger School on property belonging to the S. S. Finger estate. About 1,000 feet south of the schoolhouse, near the confluence of several small drainage lines $\left(\mathrm{NE}_{1} / 4 \mathrm{NW}_{1} / 4\right.$ sec. $7, \mathrm{~T}$. 
3 S., R. 3 E.) a 2-foot ledge of hard bauxite crops out over several hundred square feet. About 200 feet southwest of the ledge, 3 feet of clay-ball conglomerate and several boulders of hard bauxite are found in the streambed. Half a mile down the stream, just across the Benton County line (NE1/4 sec. 12, T. 3 S., R. 2 E.), boulders of hard bauxite are found in the streambank and on the slope above the stream.

Ferruginous clay-ball conglomerate crops out in two places in the streambed north of the road (SE1/4 SE1/4 sec. 1, T. 3 S., R. 2 E.). Samples from these outcrops, analyzed by the U.S. Bureau of Mines contained 24 percent alumina, 37 percent insoluble, and 23 percent iron oxide.

The principal bauxite outcrops are in the central part of the Finger area $\mathrm{E} 1 / 2$ sec. 12 , T. 3 S., R. 2 E.). Bauxite crops out on the McGill-Tapp properties ${ }^{1}$ on the point of the ridge (pl. 2) between two creeks and also in the streambed and on both sides of the valley below their junction. Morse (1923, p. 165) estimated that 330,000 tons of ore containing 34 to 42 percent alumina and 405,333 tons of ore containing 31 percent alumina were present.

Ocherous elays crop out on the ridge point below the bauxite, and a hand-auger hole at the foot of the ridge showed that these clays pass downward into bluish-gray sideritic clays of the lower unit of the bauxite-kaolin zone. Sands of the Fearn Springs Sand Member or of the main part of the Wilcox Formation overlie the bauxite.

Surface samples collected by W. G. Waldo and J. W. Adams from the McGill and Tapp properties contain a somewhat higher proportion of gibbsite than either the material penetrated in the Morse test pits or the Bureau of Mines drill holes. Differences in the methods of sampling and the condition of the sampled material probably explain the greater proportion of gibbsite. The bauxite of outcrops commonly appears more pisolitic than the material in test pits or drill holes. The prominence of the pisolites in outcrops is due to weathering and the mechanical removal of the more clayey matrix material, a fact which leaves the pisolites standing out boldly. Although the exact manner of taking these surface samples is not known, they probably consisted of small chips removed from the surface of the outcrops and a few of them were from depths of more than 2 inches below the surface. In such samples, the pisolites, protruding beyond the matrix, constitute a higher proportion of the sample. Chemical analyses supplied by W. G. Waldo, Reynolds Metals Co., showed the samples to contain about 23 to 43 percent alumina, 8 to 22 percent silica, and 23 to 42 percent iron oxide.

1 The names of the deposits as described by Morse (1923) are retained herein even if the ownership of the land has changed. 
DRILIING

Hole 1 (pl. 2) penetrated 4 feet of nonpisolitic grade D bauxite in the lower unit of the bauxite-kaolin zone at a depth of 38 feet, and the bauxite was overlain by at least 5 feet of kaolinitic clay. The bauxite, averaging 40.2 percent alumina, was the highest grade material found in the Finger area.

Holes $1,6,7,8,9$, and 10 penetrated from 4.0 to 6.0 feet of clay of the lower unit of the bauxite-kaolin zone at depths ranging from 22 to 74 feet and averaging 55 feet. On figure 3 an area of 351 acres is indicated as being underlain by clay. The clay is a very thin and, in places, sandy bed underlying a large area at considerable depth. It lies on a surface of considerable relief which is highest at the northeast end in the vicinity of the only bauxitic material and near holes 6 and 8. It occurs at a considerably greater depth between these two highs and at the southwest end of the deposit.

Analyses of the samples from the Finger area are given by Reed (1948, p. 13).

\section{SHELTON AREA, TIPPAH COUNTY}

The Shelton area (secs. 17 and 20, T. 3 S., R. 3 E.) is about 4 miles west-southwest of Falkner and 10 miles north-northwest of Ripley. The principal bauxite outcrops are on the W. D. Shelton property. The bauxite which crops out is a very pisolitic part of the clay-ball conglomerate at the base of the upper unit of the bauxite-kaolin zone, but most of the bauxite found in drilling is in the lower unit.

\section{OUTCROP}

Limonitic bauxite crops out in several places near the heads of two drainage lines on opposite sides of the ridge which is the watershed between Muddy Creek on the north and North Tippah Creek on the south (pl.2). On the northeast side of the ridge are three major outcrops. At the largest of these (SE1/4 SE1/4 sec. 17 and NE1/4NE1/4 sec. 20, T. 3 S., R. 3 E.), bauxite and kaolin crop out in a long narrow mass trending south-southwest, cut across the eastward-trending spurs of the main ridge, and disappear southward under the ridge. The bauxite and clays of the bauxite-kaolin zone penetrated by auger holes west and southwest of the outcrops suggest that the bauxite on the north side of the ridge connects under the ridge with the outcrops on the other side near the center of section 20 .

A quarter of a mile east of this exposure, clayey bauxite and kaolin crop out (SE1/4 SE1/4 SE1/4 sec. 17, T. 3 S., R. 3 E.) on the east side of a small creek. Kaolinitic clays of the lower unit of the bauxite-kaolin zone also crop out in several places below the bauxite. The bauxite does not seem to have any considerable extension underground, for 
samples still on the ground in 1942 from old hand-auger holes around the outcrop showed some clay but no bauxite.

The third outcrop is the northernmost in the Shelton area. W. D. Shelton (oral commun., Sept. 1942) dug a pit, now filled, through the outcrop and found 12 feet of bauxite and 9 feet of white clay resting on black Porters Creek Clay. According to Shelton, old hand-auger holes west of the outcrop penetrated only loose fine sand, which indicates that this outcrop is a narrow north-trending strip that was cut out on the west before deposition of sand of the Fearn Springs Sand Member of the Wilcox.

On the southwest side of the ridge ( $\mathrm{SW}^{1} / 4 \mathrm{NE}^{1 / 4}$ sec. 20, T. $3 \mathrm{~S}$., R. 3 E.), the bauxite outcrops do not present the striking alinement seen on the northeast side of the ridge, although their position suggests that they are extensions of that bauxite (pl. 2). Kaolin and silty sideritic clays of the lower unit of the bauxite-kaolin zone are well exposed in the creeks. Crystalline gypsum is present at some outcrops.

A ledge of somewhat pisolitic hard limonitic bauxite, 10 feet thick, containing a 6 -inch bed of granular siderite near the middle, crops out (NE $1 / 4$ SW $1 / 4$ NE $1 / 4$ sec. 20 , T. 3 S., R. 3 E.) about 700 feet southsouthwest of the ridge road and has exactly the trend of the outcrops on the northeast side of the ridge. Bauxite crops out for about 150 feet in the bed of the branch at this locality. A test pit dug some years ago a few yards southwest of the outcrop showed boulders of bauxite that are very similar to the outcropping material and that rest on an ocherous kaolin conglomerate. Hand-auger holes, drilled west and north of the test pit and higher than the outcrop, penetrated uncontaminated kaolin near the top of the lower unit of the bauxite-kaolin zone at the same elevation as the hard limonitic bauxite.

About 300 feet south of this outcrop, 5 feet of ferruginous clay-ball conglomerate lies on silty, gypsiferous, and sideritic clays of the lower unit of the bauxite-kaolin zone. Small boulders of hard limonitic and pisolitic bauxite are common in the bed of the stream. A few small pieces of limonitic bauxite are scattered along a terrace for more than 1,000 feet southwest of the outcrop and on the same side of the stream. The terrace was formed on the top of the lower unit of the bauxite-kaolin zone.

Many large boulders of hard limonitic pisolitic bauxite, previously referred to by Conant (1941, p. 64), lie on the tip of a small spur (near the center of sec. 20, T. 3 S., R. 3 E.) about 30 feet above the stream bed. An old test pit and an auger hole in the bottom of the pit showed that the boulders rest on a ferruginous clay-ball conglomerate near the base of the upper unit of the bauxite-kaolin zone. Auger holes halfway up the spur above the boulders failed to penetrate the hard 
bauxite but penetrated fair-quality kaolin at the expected bauxite depth. A few pieces of float are found to the north along a narrow terrace formed on the top of the lower unit of the bauxite-kaolin zone.

Several feet of ocherous kaolin conglomerate is exposed in a woods road (NW1/4 NE $1 / 4 \mathrm{SW}^{1} / 4$ sec. 20 , T. 3 S., R. 3 E.) along the side of a ridge. This conglomerate probably also represents the lower unit of the bauxite-kaolin zone.

\section{DRILIING}

The locations of the 24 drill holes and the areas underlain by bauxite and clay are shown in plate 2 . Bauxite and clay were penetrated by drill holes at depths ranging from 17 to 75 feet and averaging 45 feet. Thicknesses of bauxite and clay ranged from 3 feet in hole 25 to 19 feet in hole 28 . The bauxite is invariably mixed with clay and in mining would be difficult to identify and segregate from the clay. The analyses of bauxite and clay from drill holes are given by Reed (1948, p. 13-14).

Figure 2 shows isopach maps of grade $\mathrm{C}$ bauxite, grade $\mathrm{D}$ bauxite, and kaolinitic clay in the deposit. Thicknesses of material indicated on figure 2 for deposits $\mathrm{A}, \mathrm{B}$, and $\mathrm{C}$ are the minimum thicknesses present. Both the grade $\mathrm{C}$ and the grade $\mathrm{D}$ deposits are overlain and underlain by kaolinitic clay. The isopach maps strongly suggest that additional drilling north and northwest of holes 19, 20, and 22 would substantially increase the measured tonnage of low-grade material.

Grade $\mathrm{C}$ bauxite, the nighest grade found, was penetrated only in hole 13, where it was 5.5 feet thick (fig. 2, deposits $A$ and $C$ ). It is a part of the lower unit of the bauxite-kaolin zone and is at a depth of 42 feet. The bauxite is probably a small remnant of a deposit largely removed before deposition of the upper unit of the zone. Most of the grade $D$ bauxite is a separate body in the northeastern part of the deposit and ranges from 3 to 9 feet in thickness and averages 5 feet. It is also in the lower unit of the bauxite-kaolin zone and may be called a bauxitic clay or a kaolin conglomerate. A minor amount of the grade $\mathrm{D}$ bauxite, however, is a part of the conglomerate at the base of the upper unit in places where the conglomerate contains many pisolites and is relatively free from sand and siderite. The kaolinitic clay body, which underlies and surrounds the grade $\mathrm{C}$ and grade D lenses, is chiefly the lower unit of the bauxite-kaolin zone, but some of the overlying material is the conglomerate at the base of the upper unit. 


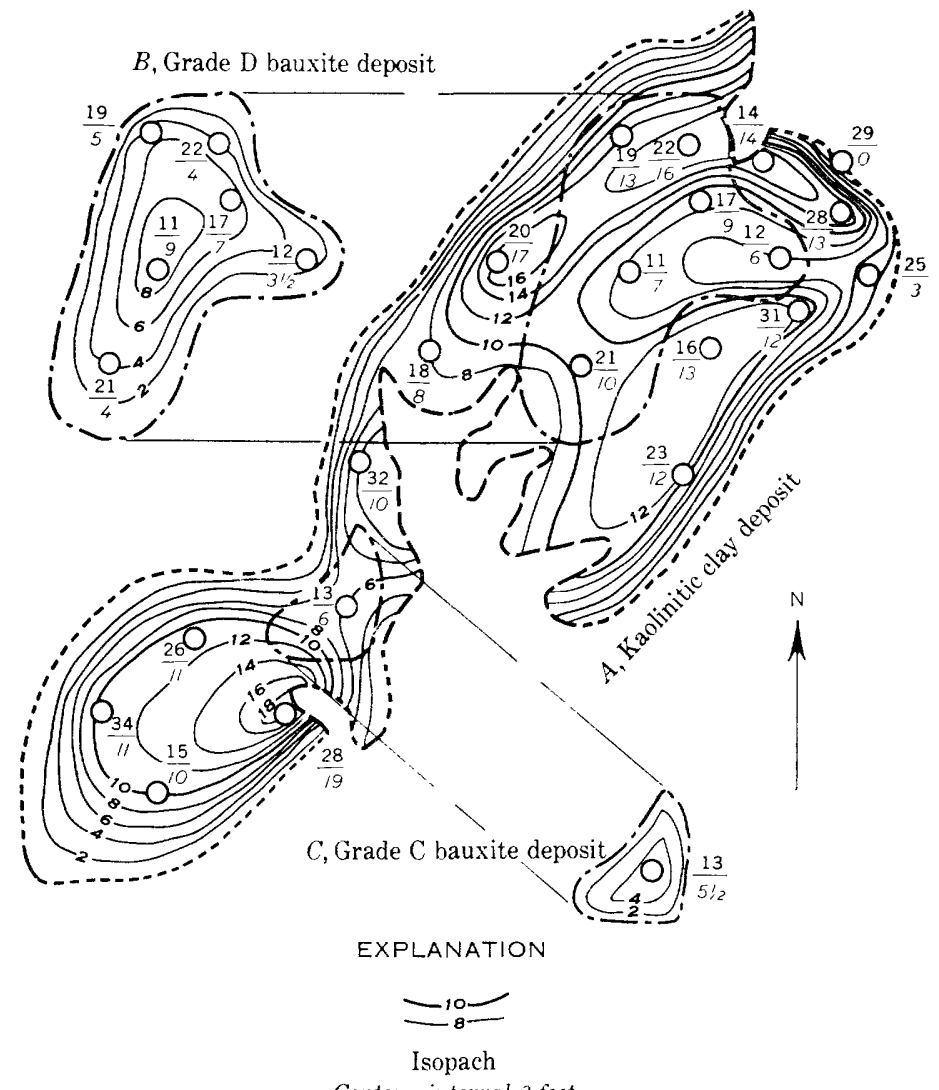

Contour interval afeet

$\frac{28}{19} \mathrm{O}$

Drill hole

Top number is hole number; bottom is thickness of bauxite or clay, in feet

Outcrop of deposit

Assumed edge of bauxite deposit underground

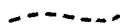

Assumed edge of clay deposit underground

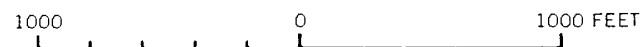

Frgure 2.-Bauxite and clay deposit found by drilling, Shelton area, Tippah County, Miss. 


\section{SHADY GROVE AREA, TIPPAH COUNTY}

Bauxite and kaolin crop out at the north, south, and east edges of the community of Shady Grove and in two places about 2 miles north of the community (pl. 2).

\section{OUTCROP}

A bed of hard ocherous kaolin conglomerate, 3 feet thick, resting on a unit of 13 feet of massive ocherous kaolin overlain by sand, is exposed in the roadbank 0.2 of a mile east of Shady Grove (SW1/4 NW1/4 sec. 12, T. 4 S., R. 2 E.) on the B. L. Shelton-Walker properties. The kaolin is also exposed 1,000 feet north of the road and about 200 feet southwest of the road outcrop. Porters Creek Clay crops out along the road several hundred feet east of the kaolin. According to an analysis by Burchard (1925, p. 119), the kaolin contains 36.18 percent alumina, 47.32 percent silica, 1.08 percent iron oxides, and 1.60 percent titania. Limonitic bauxite float is found in several of the gullies below the kaolin.

Conant (1941, p. 58) reported kaolinitic clay 0.3 of a mile west of Shady Grove (SE $1 / 4$ sec. 11, T. 4 S., R. 2 E.) on the E. P. Barber property. Limonitic bauxite float lies on the Porters Creek Clay on the east side of a low ridge about 1,800 feet southwest of the kaolin outcrop and also on the west side of the main Shady Grove ridge about 1,500 feet southeast of the kaolin outcrop.

Ocherous and limonitic pisolitic bauxite crops out in a woods road (SE1/4NE1/4 sec. 11, T. 4 S., R. 2 E.) nearly 0.2 of a mile north of Shady Grove and 200 feet west of the main road on property owned by the S. S. Finger estate. The pisolites are softer than the matrix. This bauxite is an isolated outcrop.

The most striking outcrop of bauxitic material in Tippah County is on the south side of the Caney Creek valley (SW1/4 sec. 36, T. $3 \mathrm{~S} ., \mathrm{R}$. 2 E.), 2 miles north of Shady Grove on the W. T. Meadows property. Outcrops and float boulders of hard limonitic bauxitelike material extend for nearly half a mile north and south across the tips of the westward-trending ridges. A test pit sunk by the Reynolds Metals Co. at the side of the woods road near the north end of the deposit, showed 40 feet of limonitic bauxitic material resting on white clay. In 1942, the U.S. Bureau of Mines enlarged this pit to obtain a 50-ton sample for experiments with the Pederson electric furnace process. A test pit 0.1 of a mile south of this road shows 15 feet of bauxitic material, but outcrops 0.4 of a mile south of the road show only 2 or 3 feet of bauxitic material. The deposit has an apparent outcrop width of about 400 feet.

The outcrops and float boulders are of very limonitic hard pisolitic bauxite, but the test pits and the excavation by the U.S. Bureau of 
Mines show a limonitic or sideritic clay-ball conglomerate carrying only a few pisolites. The material is typical of the conglomerate at the base of the upper unit of the bauxite-kaolin zone.

Silty kaolinitic clays of the lower unit of the bauxite-kaolin zone are poorly exposed along the stream about a quarter of a mile southeast of the main body of the Meadows bauxite deposit on the GravesHolly Springs National Forest properties. Hand-auger holes near the outcrops showed no extension of clean kaolin. The overburden thickens abruptly above the outcrops, and to the north the clay was eroded away prior to deposition of the main part of the Wilcox Formation.

\section{DRILLING}

Most of the drilling in the Shady Grove area was in two general places, one near the W. T. Meadows outcrop and the other near the outcrops close to Shady Grove. In addition, two holes were drilled along the road connecting the two places. The location of the holes is shown on plate 2 .

Five holes were drilled north, east, and southeast of the Meadows outcrop. The northernmost hole, No. 35, penetrated a clay-ball conglomerate which consists of reworked material from the base of the upper unit of the bauxite-kaolin zone. This material was redeposited in the lower part of a Wilcox channel which cuts across the north end of the deposit. Chemical analyses of a 20 -foot interval in the hole indicated only a sandy and ferruginous clay. The channel limits a continuation of the bauxite to the north.

Holes $36,37,38$, and 39, east and southeast of the outcrop, partly delimited an underground extension of the outcrop to the southeast. Holes 36, 37, and 38 penetrated clay-ball conglomerate at the base of the upper unit of the zone, but none of this material, stratigraphically equivalent to the pisolitic bauxite in the outcrop, contained sufficient alumina to be classified as bauxite. These three holes also went through the underlying bauxite and clay of the lower unit. The highest-grade bauxite penetrated was grade D. In hole 36 the bauxite was nonpisolitic and low in iron, but in hole 38 it was extremely high in iron. Hole 39, outside the ore body, penetrated laminated clayey silts and fine clayey sands of the main part of the Wilcox Formation resting directly on black marine Porters Creek Clay. On the west side of the Meadows deposit the bauxite-kaolin zone was cut out before the deposition of the later Wilcox sediments.

Chemical analyses of drill-hole samples taken by Reed (1948, p. 15) show the high silica content and generally high iron content of the deposit.

This body may extend as far southeastward as the clay exposed in the Graves-Holly Springs National Forest deposit. Additional ma- 
terial comparable to that in hole 36 could also possibly be found by drilling north and east of hole 36 .

Holes 40, 41, 42, and 43, along the ridge south of the Meadows deposit and at Shady Grove, passed through sand and into the Porters Creek Clay without penetrating the bauxite-kaolin zone. There is apparently no extension of the zone in these topographically high and favorable places.

Hole 44, in the B. L. Shelton deposit, penetrated clay in the lower unit of the bauxite-kaolin zone underlying fine sand. An 18-foot interval of these clays, beneath 31 feet of sand, had an average content of 37.8 percent alumina, 43.1 percent silica, 3.7 percent iron oxide, and 2.0 percent titania.

\section{BLUE MOUNTAIN AREA, TIPPAH COUNTY OUTCROP}

Bauxite capping the tip of a spur ridge (SE1/4 SE1/4 sec. 36, T. 4 S., R. 2 E.), half a mile north of Blue Mountain, on the property of A. J. and Callie Guyton and close to the old Macedonia cemetery, is one of the two occurrences of "puddingstone" in Mississippi mentioned by Hilgard (1860, p. 14), although he gave the locality as sec. 1, T. 5 S., R. 2 E., just over the section line. The bauxite is hard, limonitic, and pisolitic, some of the pisolites being compound. Clays of the lower unit of the bauxite-kaolin zone and a kaolin conglomerate resting on the Porters Creek Clay are exposed 600 feet south-southwest of the bauxite, around the edges of a field where a spur joins the main ridge (pl. 1). No other outcrops of bauxite or white clay are present in the area.

\section{DRIIIING}

Hole 45, about 400 feet south of the kaolin outcrop and hole 46, about 400 feet west of the outcrop, penetrated loose sand of the Wilcox Formation directly overlying the black Porters Creek Clay; this fact indicates that sediments of the bauxite-kaolin zone are absent under this part of the main ridge.

Hole 47 in the center of the bauxite outcrop (pl. 1) went through 9 feet of limonitic pisolitic bauxite, overlain by 4 feet of material chemically analyzed as clay and underlain by an additional 5 feet of clay which is high in alumina. Analyses of the five samples are given by Reed (1948, p. 15).

Recovery was very poor from a depth of 4 to 8 feet and 10 to 13 feet owing to the pisolitic nature of the rock. The recovered material consisted mainly of pisolites and a little sludge derived from ground pisolites and matrix. As most of the alumina is probably concentrated in the pisolites, the analyses of these samples show a greater percentage of alumina than may be characteristic of the bulk rock in the ground. 


\section{FLAT ROCK CHURCH AREA, BENTON COUNTY}

Bauxitic clay and kaolinitic clay crop out west and northwest of Flat Rock Church, 4 miles west-southwest of Blue Mountain. The church is very nearly on the site of the old Hurley School mentioned by Hilgard (1860, p. 113). The location of outcrops is shown on plate 2.

\section{OUTCROP}

A bed of very slightly bauxitic clay 6 to 8 feet thick crops out in a stream ditch (NW1/4 sec. 16, T. 5 S., R. 2 E.) a quarter of a mile west of Flat Rock Church on the Salvation Army property. The clay contains 41.87 percent alumina, 42.62 percent silica, 0.48 percent iron oxide, and 0.95 percent titania (Conant, 1941, p. 60; McCutcheon, 1941, p. 130). Silty and sideritic clays of the lower unit of the bauxitekaolin zone underlie this clay and are continuously exposed for about three-eighths of a mile down stream. These underlying clays grade downward into laminated and micaceous Porters Creek Clay.

An outcrop showing 6 feet of tough, nonplastic cream-colored, kaolinitic clay with a few clay balls or pisolites is found in a small stream bluff about half a mile northwest of Flat Rock Church (NW1/4 SW $1 / 4$ sec. 9, T. 5 S., R. 2 E.) on the J. M. Gunter estate. A nearby auger hole penetrated 10 feet of clay containing 36.84 percent alumina, 42.52 percent silica, 1.85 percent iron oxide, and 1.63 percent titania (Conant, 1941, p. 62; McCutcheon, 1941, p. 130). Silty and sideritic clays of the lower unit of the bauxite-kaolin zone crop out for nearly a quarter of a mile east and west of the kaolinitic clay.

\section{DRILLING}

Five holes were drilled in the Flat Rock Church area. Of these, holes $49,50,51$, and 52 penetrated between 2 and 10.5 feet of nonsilty to very slightly silty kaolin in the lower unit of the bauxite-kaolin zone. The probable extent of the kaolinitic clay body is shown on plate 2. Overburden ranges from 33 to 58 feet in thickness, increasing to the north.

Chemical analyses were made of samples from holes 49, 50, and 51 . These showed a high-grade kaolin having a uniformly low iron content. Samples from hole 52 were not analyzed, but 7 feet of kaolin similar in appearance to that in the other holes was penetrated at a depth of 58 feet. The analyses are given by Reed (1948, p. 15).

There is no evidence that the kaolin was eroded before the deposition of overlying beds of the Wilcox Formation. The altitude of the top of the kaolin in each hole is similar and shows gradual decrease to the north. However, closer spacing of holes might indicate small-scale erosion not detected by this drilling. The present drainage system is 
not considered to have removed much of the deposit because the outcrops are in the bottom of streambeds which are lower than other drainage lines in the area underlain by the kaolin.

\section{MINOR OCCURRENCES OF BAUXITE AND KAOLIN}

The following deposits, shown on plate 1, are of minor commercial importance in that they are isolated or small bodies near which there is little likelihood of finding extensions by drilling and in that they consist of groups of outcrops having possibilities of extension but containing too little alumina to be of possible commercial interest.

\section{TIPPAH COUNTY}

Hopper-Martindale-Holly Springs National Forest.-Conant (1941, p. 55-56) estimated that 50 to 75 acres, lying in parts of the SE1/4 sec. 28 , the SW1/4 sec. 27 , and the NE1/4 sec. 33 , T. 2 S., R. 3 E., about $31 / 2$ to 4 miles northwest of Falkner, are underlain by kaolin and kaolinitic clays. One hand-auger hole (A155) penetrated 7.9 feet of kaolin which contained (McCutcheon, 1941, p. 162) 38.51 percent alumina, 46.37 percent silica, 1.2 percent iron oxide, and 0.9 percent titania. Another hole (A121) penetrated 4.7 feet of kaolin which contained 39.74 percent alumina, 44.58 percent silica, 0.6 percent iron, and 1.3 percent titania (McCutcheon, 1941, p. 162).

Patrick-Harrell.-A kaolin conglomerate overlying silty clays of the bauxite-kaolin zone is exposed along the road on the Patrick and Harrell properties ( $1 / \frac{1}{2}$ sec. 33, T. 2 S., R. 3 E.). Hand-auger holes drilled by Conant (1941) penetrated only pottery clays.

J.C.McElwain.-Small fragments of bauxite and loose pisolites are found in the colluvium on the southwest side of a hill $\left(\mathrm{SW}^{1} / 4 \mathrm{NW}^{1 / 4}\right.$ sec. 10, T. 3 S., R. 3 E.) $21 / 4$ miles west of Falkner on the Ashland road and about 800 feet southwest of the road. Clays of the lower unit of the bauxite-kaolin zone are exposed in the roadcut. In prospecting for clays similar to those exposed in the road, Conant (1941, p. 100) found 7 feet of "pisolitic" clay in an auger hole near the area in which the float is found. This clay was probably a kaolin conglomerate.

L. S. Pearce.-A few pieces of ferruginous bauxite float were found on both sides of the road a few hundred feet west of the Pearce residence, about $31 / 4$ miles west of Falkner (NE1/4 SW1/4 sec. 4 , T. 3 S., R. $3 \mathrm{E}$.). Clays of the lower unit of the bauxite-kaolin zone are exposed above the float, and the Porters Creek Clay crops out a few feet below the float areas. The bauxite apparently has been let down from above, and the ridge along which the float is found is too low for any possible extension. 
I. V. James (Mississippi Bauxite Co.).-Bauxite caps an isolated elliptical hill (NE1/4NE1/4 sec. 4, T. 3 S., R. 3 E.) 2 miles northwest of Falkner and covers an area about 600 feet long and 200 feet wide. Morse (1923, p. 155-156) found 7 to 12 feet of bauxite and bauxitic clay. The single analyzed sample contained 47.75 percent alumina, 27.24 percent silica, 2.15 percent iron oxide, 2.40 percent titania, and 19.76 percent loss on ignition. He estimated that 26,250 tons of ore containing 48 percent alumina was present. The bauxite is composed of pisolites, some of which are compound, as much as 1 inch in diameter, in a very sandy clay matrix. Burchard $(1925$, p. 117) gave an analysis of a single pisolite which contained 59.58 percent alumina.

J. C. James (Mississippi Bauxite Co.).-A few boulders of ferruginous bauxite are found on a low hill (NE1/4NW1/4 sec. 4, T. 3 S., R. $3 \mathrm{E}$.) half a mile east of the I. V. James property. The top of the hill is about 1,000 feet long and 500 feet wide. A few feet of impure kaolin and silty sideritic clays of the lower unit of the bauxite-kaolin zone were found under the bauxite boulders in hand-auger holes drilled on top of the hill.

Green Wattes (Mississippi Bawxite Co.).-Bauxite crops out on a ridge point (NW1/4 sec. 4 , T. 3 S., R. 3 E.) an eighth of a mile south of the J. C. James-Mississippi Bauxite Co. occurrence. Large boulders of the ferruginous bauxite have moved down hill from the outcrops, particularly on the northeast side of the hill. Morse (1923, p. 158-159) found 2.5 to 10.3 feet of soft and hard bauxite, and the single analyzed sample contained 40.58 percent alumina, 26.96 percent silica, 4.72 percent iron oxide, 2.20 percent titania, 16.33 percent loss on ignition, and 9.25 percent moisture. A thin bed of ferruginous sandstone was found within the bauxite, a fact suggesting that the bauxite is the conglomerate at the base of the upper unit of the bauxite-kaolin zone. A narrow ridge of loose sand extends for about 100 feet over the bauxite, but the configuration of the area over which the bauxite crops out suggests that the deposit does not extend very far under this cover.

W. M. Dodson.-Boulders of ferruginous bauxite are found on a low ridge near the stream bottom an eighth of a mile northwest of the Little Hope Crossroads (SW $1 / 4$ NE $1 / 4$ sec. 5, T. 3 S., R. 3 E.). This bauxite is mentioned by Burchard (1925, p. 118) who said: "This rock $* * *$ is regarded as carrying between 30 and 38 percent of alumina." Soft sandy kaolin conglomerate crops out in the road ditch at the Little Hope Crossroads and in an old storm cellar 100 feet east of the Dodson residence at the crossroads. More than 10 feet of clean massive kaolin is exposed 800 feet west of the crossroads. Hand-auger holes penetrated as much as 11 feet of the kaolin conglomerate overlying the light bluish-gray sideritic clays which grade downward into 
the Porters Creek Clay. The area underlain by the conglomerate is long and narrow and extends from the crossroads northwest towards the bauxite outcrop. The ferruginous bauxite is probably the indurated form of the kaolin conglomerate. No analyses are available.

P. W. Caviness (Thad Hill).-A low mound of ferruginous bauxite about 50 feet in diameter lies at the junction of two branches about half a mile west of the Little Hope Crossroads (NE1/4 SW $1 / 4$ sec. 5, T. 3 S., R. 3 E.). Kaolin conglomerate crops out several hundred feet to the southwest in gullies along the east side of a hill. Morse (1923, p. 159-160) dug one test pit through the outcrop; the best of the three samples from this pit contained 41.2 percent alumina, 32.6 percent silica, 6.4 percent iron oxide, and 1.3 percent titania, recalculated to a dry basis.

$J$. P. Clemmer.-Kaolin, only slightly contaminated by sand and silt, is exposed on a level bald spot on the top of a small hill (NE1/4 SE $1 / 4$ sec. 8 , T. 3 S., R. 3 E.) nearly a mile south of the Little Hope Crossroads. Small pieces of somewhat ocherous kaolin conglomerate are strewn over the bald spot. Silty clays of the lower phase of the bauxite-kaolin zone crop out below the kaolin.

$J$. W. Jones.-Boulders of hard ferruginous bauxite are found over an area of several hundred square feet on a ridge point ( $\mathrm{SE} 1 / 4 \mathrm{NE} 1 / 4$ sec. 22, T. 3 S., R. 3 E.) 1,100 feet north-northeast of the Unity Schoolhouse 6 miles northwest of Ripley. A sandy clay-ball conglomerate crops out in the road about 1,000 feet north of the schoolhouse and 500 feet west of the bauxite boulders. Silty clays of the bauxite-kaolin zone are exposed beneath the clay-ball conglomerate.

F. O. Hudspeth.-Bauxite occurs over an area 400 feet long and 150 feet wide on the top of a small isolated hill 1.2 miles west of Blue Mountain (SE $1 / 4$ NE $1 / 4$ sec. 11, T. 5 S., R. 2 E.). About 6 feet of slightly ocherous bauxite is exposed in a woods road near the south end of the deposit. The dump piles around the two test pits, one at each end of the deposit, show white bauxite containing soft pisolites. The test pits are now filled with debris, but Burchard (1925, p. 120) reported 3 to 4 feet of hard light-colored bauxite and bauxitic clay. No analyses are available.

E. M. Hardin.-Bauxite caps a small hill 3 miles northwest of Blue Mountain (NW1/4NE1/4 sec. 35, T. 4 S., R. 2 E.), where Conant (1941, p. 64) found 8 feet of very low-grade material.

$C$. F. Godwin.-Sandy kaolin conglomerate is exposed in a spring 500 feet west of a tenant house at the southeast end of a ridge (SE1/4 NW1/4 sec. 27 , T. 4 S., R. 2 E.) on the Godwin property about 4 miles northwest of Blue Mountain. The Porters Creek Clay is exposed in a woods road 12 feet below the conglomerate, and a coarse red sand lies on the conglomerate. No other outcrops were found in the vicinity. 


\section{BENTON COUNTY}

$J$. R. Hunter.-In a spring several hundred feet southeast of the Hunter residence on a tributary to the west fork of Grays Creek (SW1/4 NE $1 / 4$ sec. 33, T. 4 S., R. 2 E.), a silty kaolin conglomerate and silty kaolin of the lower unit of the bauxite-kaolin zone are exposed. Porters Creek Clay is exposed in the bed of the creek below the spring. A seepage zone at the level of the spring is conspicuous for about 300 feet south of the spring, but no other indication of the bauxite-kaolin zone could be found.

\section{RESERVES}

A reserve of 3,637,000 long tons of low-grade bauxite and kaolinitic clay is estimated to occur in Tippah and Benton Counties. Of this estimated tonnage, 17,000 tons is grade $\mathrm{C}$ bauxite, 112,000 tons is grade $\mathrm{D}$ bauxite, and the remainder, 3,508,000 tons, is kaolinitic clay. The low alumina content of the bauxite and clay, the thin beds in which they occur, and the thick overburden seem to combine to make the development of any of these deposits unlikely.

In making the estimates, bodies and parts of bodies to a minimum thickness of 2 feet were included. A factor of 22.4 cubic feet of bauxite or clay per long ton was used in the calculations. All data were interpreted conservatively, and estimates may be correct to within 30 percent in the Shelton, Shady Grove, and Blue Mountain areas and to within 50 percent in the Finger and Flat Rock Church areas. The pertinent data on the bauxite and clay resources found by drilling are summarized in tables 1 and 2.

Additional drilling in the Finger, Shelton, Shady Grove, and Flat Rock Church areas would probably reveal more clay and perhaps a little more low-grade bauxite, but it is not likely that any such additional clay and bauxite would be found under conditions more favorable for mining than those already known. The geology of a few outcrops of the bauxite-kaolin zone suggests that similar low-grade material under deep cover might be found by drilling in the following areas: north of the Falkner-Ashland road from the Little Hope Church to the Finger school (N1/2 secs. 5 and 6, T. 3 S., R. 3 E., W1/2 sec. 33, T. 2 S., R. E., Tippah County), north of Shady Grove (SW1/4 sec. 36, T. 3 S., R. 2 E., Tippah County), and northeast of Flat Rock Church under the wide ridge between Grays and Godwin Creeks (part of sec. 33, Benton County, part of secs. 27 and 34, Tippah County, all in T. 4 S., R. 2 E., secs. 4 and 9, Benton County, sec. 3 and the N1/2 sec. 10, Tippah County, all in T. 5 S., R. 2 E.). 


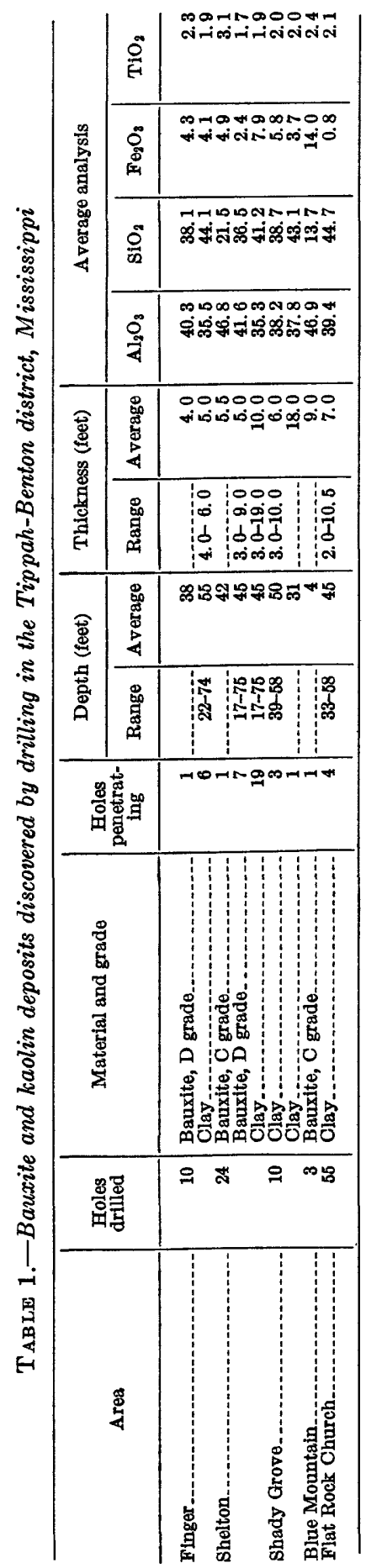


Table 2.-Estimated reserves of bauxite and kaolin discovered by drilling in the Tippah-Benton district, Mississippi

Estimated long tons

Bauxite, C grade 17,000

Bauxite, D grade 112,000

Kaolinitic clay $3,508,000$

Total $3,637,000$

There is little hope of finding bauxite in Mississippi suited to present processes (1960), and unless the low-grade material becomes usable on some commercial basis, there would be little reason for further prospecting in Tippah and Benton Counties.

\section{LITERATURE CITED}

Burchard, E. F., 1925, Bauxite in northeastern Mississippi : U.S. Geol. Survey Bull. 750-G, p. 101-146.

Conant, L. C., 1941, Tippah County mineral resources; Geology : Mississippi Geol. Survey Bull. 42, p. 11-110.

Fenneman, N. M., 1938, Physiography of eastern United States: New York, McGraw-Hill Book Co., 714 p.

Hilgard, E. W., 1860, Report on the geology and agriculture of the State of Mississippi : Jackson, Miss., E. Barksdale, State Printer, 391 p.

McCutcheon, T. E., 1941, Tippah County mineral resources-Tests : Mississippi Geol. Survey Bull. 42, p. 111-202.

MacNeil, F. S., 1946, Summary of Midway and Wilcox stratigraphy of Alabama and Mississippi: U.S. Geol. Survey Strategic Minerals Inv. Prelim. Rept. 3-195, 29 p.

Morse, P. F., 1923, The bauxite deposits of Mississippi : Mississippi Geol. Survey Bull. 19, $208 \mathrm{p}$.

Reed, D. F., 1948, Bauxite deposits in Tippah and Benton Counties, Mississippi : U.S. Bur. Mines Rept. Inv. 4281, 15 p.

Thoenen, J. R., and Burchard, E. F., 1941, Bauxite resources in the United States: U.S. Bur. Mines Rept. Inv. 3598, 42 p. 
